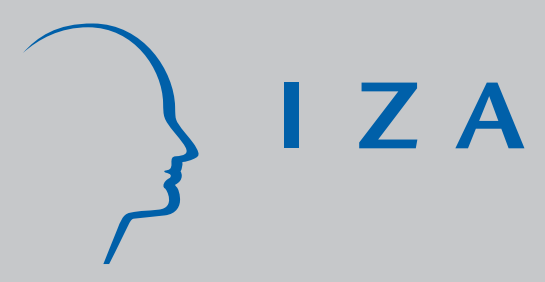

IZA DP No. 3241

Employment Protection Reforms, Employment and the Incidence of Temporary J obs in Europe: 1995-2001

Lawrence M. Kahn

December 2007 


\title{
Employment Protection Reforms, Employment and the Incidence of Temporary Jobs in Europe: 1995-2001
}

\author{
Lawrence M. Kahn \\ Cornell University, \\ CESifo and IZA
}

\section{Discussion Paper No. 3241 \\ December 2007}

\author{
IZA \\ P.O. Box 7240 \\ 53072 Bonn \\ Germany \\ Phone: +49-228-3894-0 \\ Fax: +49-228-3894-180 \\ E-mail: iza@iza.org
}

Any opinions expressed here are those of the author(s) and not those of the institute. Research disseminated by IZA may include views on policy, but the institute itself takes no institutional policy positions.

The Institute for the Study of Labor (IZA) in Bonn is a local and virtual international research center and a place of communication between science, politics and business. IZA is an independent nonprofit company supported by Deutsche Post World Net. The center is associated with the University of Bonn and offers a stimulating research environment through its research networks, research support, and visitors and doctoral programs. IZA engages in (i) original and internationally competitive research in all fields of labor economics, (ii) development of policy concepts, and (iii) dissemination of research results and concepts to the interested public.

IZA Discussion Papers often represent preliminary work and are circulated to encourage discussion. Citation of such a paper should account for its provisional character. A revised version may be available directly from the author. 


\section{ABSTRACT \\ Employment Protection Reforms, Employment and the Incidence of Temporary Jobs in Europe: 1995-2001*}

Using European Community Household Panel data for nine countries for 1996-2001, I investigate the impact of reforms of employment protection systems on employment and on temporary jobs for wage and salary workers. Individual fixed effects models are estimated, with the inclusion of country-specific trends in the dependent variable, addressing the possibly changing labor force composition and the possible endogeneity of the reforms. A basic finding that is robust to all specifications and to the disaggregation of the sample by country is that policies making it easier to create temporary jobs raise the likelihood that wage and salary workers will be in temporary jobs. However, there is no evidence that such reforms raise employment, and in some countries, they appear to lower employment. Thus, these reforms appear rather to encourage a substitution of temporary for permanent work. Reforms of permanent employment protection mandates have small and insignificant effects on employment and temporary jobs on average. Moreover, when I disaggregate by country, such reforms appear more often to lower overall employment and to lower the share of employment in permanent jobs. These are likely to reflect short run impacts of such reforms, which make it easier for firms to discharge substandard workers.

JEL Classification: J21, J23

Keywords: employment protection, temporary jobs

Corresponding author:

Lawrence M. Kahn

Cornell University

362 Ives Hall East

Ithaca, NY 14853

USA

E-mail: Imk12@cornell.edu

\footnotetext{
* This paper uses European Community Household Panel data (Users Database, waves 1-8, version of December 2003), supplied courtesy of the European Commission, Eurostat. Data are obtainable by application to Eurostat, which has no responsibility for the results and conclusions of this paper.
} 


\section{Introduction}

A considerable volume of economic research has been devoted over the last two decades to explaining and suggesting remedies for the stubbornly high unemployment rates in a number of European countries. Among the suggested policy remedies for reducing joblessness is the relaxation of systems of employment protection by reducing the mandated costs to firms of firing workers. Some have argued that such reforms encourage job creation by reducing future downsizing costs or the costs of firing unproductive workers; however, the reforms may also raise the number of employee discharges, potentially undoing the reforms' effects on unemployment (OECD 2004). While some reforms lower the costs of firing workers from permanent jobs, most reforms in recent years have been directed at easing restrictions on the use of temporary employment contracts. These reforms presumably reflect a desire to maintain protections for workers in permanent jobs while giving firms an incentive to create new, temporary jobs, which may ultimately become permanent. ${ }^{1}$ However, such policies may instead encourage firms to substitute temporary for permanent jobs, and, if so, the overall exit rate from jobs may increase. The resulting higher turnover may even lead to higher equilibrium unemployment than before (Blanchard and Landier 2002). Moreover, temporary jobs are known to pay less, offer less training, and be less satisfying than regular jobs (Booth, Francesconi and Frank 2002; Kahn 2007). Thus, reforms that encourage the creation of temporary jobs may not lower unemployment and also may not unambiguously raise employed workers’ utility (Blanchard and Landier 2002).

This paper studies the effects of employment protection system reforms in nine European countries during the 1996-2001 period. The countries are Belgium, Finland, France, Germany, Italy, the Netherlands, Portugal, Spain and the United Kingdom. During the post-1990 period, the most common reform of employment protection laws (EPL) among these and other OECD countries has been to relax restrictions on the use of temporary contracts. For example, in some

\footnotetext{
1 Evidence on the question of whether temporary jobs are stepping stones to permanent jobs is mixed. See Booth, Francesconi and Frank (2002) and Autor and Houseman (2005).
} 
cases, firms were allowed to renew their temporary employment contracts additional times. This type of reform may be the easiest to accomplish politically since it leaves intact any basic protections on permanent employment (Brügemann 2007). However, as shown below, there were also some reforms in which protections on permanent jobs were relaxed as well as some where protection on permanent jobs or restrictions on temporary jobs were increased. This diversity of change will provide us some useful variation in order to estimate the impact of these reforms.

To examine the effects of EPL reforms, I use longitudinal data from the European Community Household Panel (ECHP) for the nine countries mentioned above. Microdata are helpful in estimating the impact of reforms since they allow one to control for composition effects. For example, groups in the labor force that typically work disproportionately in temporary jobs such as the young, women or immigrants may be increasing their labor force share at the same time as reforms are being enacted. If so, then macroeconomic comparisons of the incidence of temporary jobs before and after reforms may confound these compositional effects with the true effects of the reforms. In addition, previous theoretical and empirical research suggests that the impact of employment protection on the incidence of temporary jobs will be felt disproportionately by the young, women, immigrants, and the less skilled (Kahn 2006 and 2007). Having microdata will allow one to test these hypotheses as well.

The longitudinal nature of the ECHP sharpens one's tests of the impact of the reforms. Specifically, by estimating individual fixed effects models, one can observe outcomes for the same individual in an environment without and one with labor market reforms. Such a research design can alleviate possible biases due to non-random changes in the composition of the population at the time of the reforms, even controlling for its measured characteristics. For example, new cohorts of women may have different attitudes toward temporary work (compared to previous cohorts) around the time of reforms. Again, the incidence of temporary work among women may be changing for these compositional reasons rather than due to the reforms. However, by observing the same worker over time, we can provide a more valid test. Of course, 
individuals' attitudes may be changing at the time of reforms, making even the fixed effects approach suspect. I will address such concerns by including country-specific trends in some models. Moreover, this design can in principle at partially account for the potential endogeneity of reforms. For example, to the extent that reforms reducing workers' protection become more politically viable during expanding labor markets (a possible outcome in political economy models of reforms such as those of Saint-Paul 2002 and Brügemann 2007), failure to control for country trends may lead us to mistakenly credit reforms for creating jobs.

I estimate the effects of reforms both pooling the nine countries as well as separately by country. My basic results for the pooled sample of countries illustrate the value of controlling for pre-existing trends in estimating the impact of reforms on employment outcomes. Specifically, not controlling for country-specific trends, reducing restrictions on firing workers from permanent jobs appears to raise employment and to raise the incidence of permanent work among the employed, as the reforms were intended to do. However, these effects become small and insignificant when I control for country-specific trends. The impact of controlling for country-specific trends suggests that countries are most likely to enact reforms liberalizing their permanent job protection regulations when the incidence of employment and permanent employment is rising. And, not controlling for trends, making it easier to create temporary jobs does not affect employment but raises the incidence of such jobs among the employed, and these findings hold up even controlling for country-specific trends. Thus, making it easier to create temporary jobs does appear to cause a greater relative incidence of such jobs, although the lack of a positive aggregate employment effect of such reforms suggests that firms are induced to substitute temporary for permanent jobs.

When I disaggregate by country, I continue to find robust evidence in nearly every case that making temporary jobs easier to create raises the relative incidence of temporary employment among wage and salary workers. The findings for the impact of temporary employment reforms on employment and for the impact of permanent employment protection reforms on both dependent variables are somewhat heterogeneous across countries. However, in 
general, these reforms have more negative than positive effects on employment, and permanent employment protection reforms generally have more negative than positive effects on the incidence of permanent jobs. I suggest that liberalizing permanent protection reforms have opposing theoretical effects on employment as well as the incidence of permanent jobs: on the one hand, they make it easier for firms to fire incumbent workers, thus tending to lower permanent employment; on the other hand, they may lower the cost of creating permanent jobs and thus might raise permanent employment. I interpret these negative effects of permanent protection reforms on employment and permanent employment as short run impacts, where firms' initial response is to fire substandard workers. I argue that effects on job creation are likely to take much longer, and since the ECHP data on employment contract type span only 1995-2001, we are likely to be observing short term effects of reforms. It is also possible that firms anticipated that the liberalizing reforms would soon be repealed and thus only responded to the greater ease of firing current workers (Bertola and Ichino 1995). Finally, I argue that temporary employment reforms have short run and long run effects that go in the same direction, possibly explaining the robust positive effect I find that they have on the incidence of temporary work. Their mostly negative effect on employment when I disaggregate by country likely reflects the high exit rate from temporary jobs combined with an increased incentive to substitute temporary for permanent jobs. Thus, overall the liberalizing reforms we have seen in Europe in the late 1990s have not moved people into permanent jobs to any great extent, at least in the short run, but there is some evidence that temporary job reforms have caused some substitution of temporary for permanent jobs.

\section{Recent Research on the Impact of Reforms in Employment Protection Systems}

Several authors have estimated the impact of recent reforms in employment protection systems in Europe or Latin America, with most analyses focusing on a specific country. ${ }^{2}$ In

${ }^{2}$ As discussed below, the OECD (2004) performed a cross-country analysis of EPL reforms. 
some of these cases, reforms were targeted at subgroups in the labor force, providing researchers with a natural experiment in which outcomes can be compared across subgroups. For example, the Spanish reforms of 1997 reduced dismissal costs for permanent jobs for workers under 30 years old and for those over 45 years old but not for those age 30-44 (Kugler, Jimeno and Hernanz 2005). Similarly, in Colombia in 1990, dismissal costs were lowered for jobs in the formal sector but not for the informal sector (Kugler 1999). Going in the opposite direction (i.e., increasing employment protection), the UK in 1999 lowered the probation period during which workers may not sue for unfair dismissal from two years to one year (Marinescu 2007). And, Italian reforms of 1990 raised unjust dismissal costs for small firms but not for larger firms (Kugler and Pica forthcoming). In other cases, reforms were enacted uniformly across the economy. For example, Blanchard and Landier (2002) study the effect of France's policy in the 1990s of lowering costs of firing workers from temporary jobs on transitions to permanent work; and Boeri and Garibaldi (2007) study the effects on employment and productivity of Italy's late 1990s reforms which made it easier for firms to create temporary jobs.

In each of these cases, the reforms were correlated with the expected changes in labor market outcomes, suggesting a policy impact. For example, in the non-targeted reforms (i.e. that applied to all employers and workers), transitions from temporary to permanent employment in France fell in the 1990s after firing costs from temporary jobs were lowered (Blanchard and Landier 2002); and in Italy, temporary employment grew in the late 1990s after passage of reforms making it easier to create temporary jobs (Boeri and Garibaldi 2007). Among the targeted reforms (i.e. those that applied to a subset of firms or workers), shortening the probationary period in the UK was associated with a decrease in the firing hazard for workers with up to two years of tenure relative to those with more tenure (Marinescu 2007). Moreover, in Colombia, after reforms reducing dismissal costs in the formal sector, labor market turnover into and out of unemployment rose in the formal sector relative to the informal sector (Kugler 1999). And the Spanish reforms of 1997 lowering dismissal costs for older and younger workers were associated with a relative increase in permanent employment for these groups (Kugler, 
Jimeno and Hernanz 2005). Finally, the Italian reform of 1990 raising dismissal costs for firms with fewer than 15 workers was associated with reduced accessions and separations for these firms relative to larger firms (Kugler and Pica forthcoming).

Each of these studies is suggestive of an effect of reforms on employment outcomes. However, the studies of the impact of non-targeted reforms must assume that underlying trends in the dependent variable(s) are not confounded with the reforms, a possibly untenable assumption. For example, the overall labor market was deteriorating in France at the same time the reforms were being enacted, making a conclusion about the impact of the reforms tentative. Specifically, we might have expected a decline in transitions to permanent jobs even in the absence of reforms. ${ }^{3}$ And it is possible that temporary employment was growing in Italy around the time of its reforms. Moreover, the research design in the studies of targeted reforms must assume similar underlying trends in the outcome studied for the treatment group and the control group. For example, in the case of UK reforms, we must assume that the trend in the firing hazard post-1999 vs. pre-1999 was similar for those with short tenure and those with longer (i.e. at least 2 years) tenure. However, trends in employment or the incidence of permanent jobs are not likely to be neutral across labor force groups. For instance, it is well-known that employment of youth is more cyclically-sensitive than employment of adults (Bertola, Blau and Kahn 2007). The same may well be true of small firms relative to large firms. Thus, if reforms are more likely to be enacted in expanding economies and if expansion leads to a more positive permanent employment trend for youth or workers in small firms, then difference-in-difference analyses will confound these two effects. ${ }^{4}$ The reasoning just discussed implies that it could be

\footnotetext{
${ }^{3}$ Indeed, Holmlund and Storrie (2002) find that the recession in Sweden in the 1990s was a major cause of the rise in the incidence of temporary employment there.

${ }^{4}$ As suggested by the work of Saint-Paul (2002) and Brügemann (2007), political support for reforms depends on the relative impacts of the reforms on those with permanent jobs, those without permanent jobs and on the relative size of these constituencies at the time of reforms. In general, these effects will be theoretically ambiguous, as workers need to weigh the anticipated effects of the reforms on wages, the likelihood of retaining permanent jobs, and the creation of new, permanent jobs. For instance, lower firing costs may lower current workers' bargaining power but may also raise the value of being unemployed by making jobs more profitable to create.
} 
important to control for underlying trends in the incidence of employment or permanent employment in analyzing the impact of reforms of employment protection systems. ${ }^{5}$

While our ultimate interest is in the long run effects of labor market reforms on employment and permanent employment, it is important to consider the likely dynamics of such impacts. Reducing restrictions on the use of temporary contracts is likely to have both short run and long run effects increasing the incidence of temporary employment. For example, some reforms increase the number of times a firm is allowed to renew a temporary contract without turning the job into a permanent one. This kind of reform thus will decrease the short run transitions out of temporary employment. In addition, reforms making it easier to create temporary jobs may induce firms to redesign their employment systems to take advantage of such rights. Such a redesign may take time to implement and would be part of the long run impact of looser restrictions on the use of temporary jobs. Moreover, if there is a sector supplying short term services and offering temporary jobs, then easing restrictions on temporary employment will lower the relative costs of this sector. In the long run, capital will move to this sector, further raising the share of employment in temporary jobs.

In contrast to temporary employment reforms, policies reducing firing costs from permanent jobs are likely have short-run and long-run effects that do not necessarily go in the same direction. To see this, consider the basic framework proposed by Blanchard and Landier (2002) for analyzing the impact of firing costs on the incidence of temporary and permanent jobs. In their model, firms initially hire workers into temporary jobs, wait for a productivity observation and then decide whether to promote them into permanent jobs. The worker is then assumed to work in the permanent job until retirement. Modifying this framework can yield insights into the likely short run and long run effects of reforms reducing firing costs from permanent jobs. Specifically, let us assume that after a firm initially promotes a worker into a

\footnotetext{
${ }^{5}$ In addition to the single-country studies just discussed, the OECD (2004) made macroeconomic comparisons across 13 countries during the 1990-2003 period between the change in the strictness in permanent vs. temporary employment regulation and the change in the incidence in temporary employment. The OECD found the expected positive relationship, although the design there is subject to the same interpretation problems due to possible country-specific trends that I have already discussed.
} 
permanent job, a further observation on productivity is obtained. At this point, the firm can decide to fire the worker and pay firing costs or to keep the worker until retirement. Moreover, continue to assume that there is a short-term service sector in which jobs necessarily are completed over a fixed time period, and the where firms offer temporary employment contracts with little or zero firing cost.

At a labor market equilibrium in this expanded model, workers will be indifferent between entering the two sectors, and relative consumer demands for short term services and other goods also influence the relative size of the two sectors. In this model, in the sector potentially offering permanent jobs, firms initially hire workers into probationary positions and wait for a productivity observation $\mathrm{y}_{1}$. As in the Blanchard and Landier (2002) framework, the firm chooses a reservation productivity level $\mathrm{y}_{1}{ }^{*}$, which is the threshold for promoting temporary workers into a permanent job. Conditional on promotion, the firm will obtain at some time in the future an additional productivity observation $\mathrm{y}_{2}$. At this point, the firm will compare $\mathrm{y}_{2}$ to a second threshold $\mathrm{y}_{2} *$, where the worker will be retained in the permanent job until retirement if $\mathrm{y}_{2}>=\mathrm{y}_{2} *$.

As further discussed in the Appendix, this model has three predictions about the impact of lower firing costs $\mathrm{c}$ from permanent jobs. First, this policy will raise $\mathrm{y}_{2}{ }^{*}$, since lower c reduces the cost of firing a promoted worker who has turned out to be relatively unproductive. This effect will tend to lower the share of workers who are employed in permanent jobs by increasing the transition rate out of permanent jobs. Second, lower c will lower $\mathrm{y}_{1}{ }^{*}$, since lower future firing cost raises the potential gain to keeping a worker with a given level of current productivity (the option value of such a worker has risen). This effect will raise promotion rates out of temporary jobs into permanent jobs and will tend to counteract the first effect. Third, lower c lowers the overall cost of labor in the permanent job sector. Through general equilibrium effects, this outcome will lead to a relative expansion of the sector and thus increase the share of the labor force that potentially can attain a permanent job. The first of the three effects is likely to be realized before the other two. Specifically, before the reform, the firm 
already has an observation for $\mathrm{y}_{2}$ for some workers and can quickly raise its threshold $\mathrm{y}_{2}{ }^{*}$. Thus, discharging the least productive promoted workers can occur relatively quickly. However, the second effect (i.e., the higher promotion rate from temporary to permanent jobs), must await a productivity observation on those in temporary jobs. Moreover, the general equilibrium effect of raising the relative size of the permanent job sector must also await the mobility of capital out of the fully temporary job sector. Thus, the long run and short run effects of lowering firing costs from permanent jobs may proceed in opposite directions.

The relevance of this discussion of short-run and long run effects to the ECHP data is that with its short time horizon (1995-2001), the ECHP data may only allow for an incomplete observation on the long run effects of employment protection reforms. While we expect a positive effect in the case of the impact of liberalizing temporary employment reforms on the incidence of temporary employment, this discussion implies that the impact is be theoretically ambiguous in the case of permanent protection reforms.

\section{Recent Reforms of Employment Protection Systems in Selected OECD Countries}

Table 1 summarizes reforms during the 1996-2001 period in the countries with data available in the ECHP. I focus on this period because the ECHP didn't begin collecting data on individuals' employment contract type (i.e. permanent vs. temporary) until 1995. The Table shows that some countries enacted one reform, while others periodically added new reforms during this period. For example, among the countries with one reform, Belgium (1997), Germany (1996), the Netherlands (1999), and Portugal (1996) each liberalized the use of fixed term contracts or temporary work agencies. In contrast, France (2001) and the United Kingdom (2000) strengthened protections for permanent jobs. Finland, Italy and Spain each enacted multiple reforms, with Finland reducing protection on permanent jobs in stages, Italy liberalizing the use of temporary work agencies and fixed term contracts in stages, and Spain reforming its protection system, in each case seemingly in ways designed to reduce its high level of temporary 
employment. Specifically, in 1997, Spain reduced unfair dismissal compensation for permanent jobs (as discussed earlier), and in 2001, it restricted the use of fixed term contracts. In all, the Table shows 14 episodes of reforms, with eight liberalizing the use of temporary employment, one restricting it, three reducing protections for permanent jobs, and two increasing such protections. The timing and direction of these reforms will serve as identifying information allowing me to estimate the impact of reforms on employment outcomes.

\section{Data and Empirical Procedures}

As noted earlier, I use the ECHP longitudinal data base for the nine countries shown in Table 1. This is a panel data base that follows individuals over the 1994-2001 period. Beginning in 1995 for all of the countries in Table 1 except Finland and in 1996 for Finland, the ECHP asked each employed wage and salary worker whether his/her job was characterized by a fixed term contract. Specifically, each employed respondent is asked: "What type of employment contract do you have in your main job?” The possible responses are: 1) permanent employment; 2) fixed-term or short-term contract; 3) casual work or no contract; 4) some other working arrangement. For the purposes of analyzing the determinants of temporary employment, I include only those with responses 1) or 2), that is, those that state they have a permanent or a temporary employment contract. ${ }^{6}$ In estimating the determinants of employment, I use a traditional ILO-based definition, available in the ECHP. Employment under this definition will include all paid jobs, including the self-employed as well as casual workers. In addition to data on employment status and type of employment contract, the ECHP includes demographic information such as gender, age, schooling, and nativity status.

\footnotetext{
${ }^{6}$ While one might consider casual employment to be temporary, this need not be the case. However, when I included casual employees in the analysis of temporary employment and considered them to be temporarily employed, the results were qualitatively similar.
} 
I use the ECHP to estimate the determinants of being employed and, among wage and salary workers, having a temporary employment contract, as shown in equations 1) and 2), which apply to individuals age $16-65$ for person i, country c and year t:

1) Empict $_{\text {ict }}=\mathrm{a}_{0}+\mathrm{a}_{1} *$ Youth $_{\text {ict }}+\mathrm{a}_{2} *$ Female $_{\text {ict }} *$ Youth $_{\text {ict }}$

+ Youth $_{\mathrm{ict}} * \mathrm{~b}_{\mathrm{yc}}+\mathrm{a}_{3}$ Tempreform $_{\mathrm{ct}}+\mathrm{a}_{4}$ Permreform $_{\mathrm{ct}}+\alpha_{\mathrm{i}}+\phi_{\mathrm{t}}+\mathrm{u}_{\mathrm{ict}}$

2) Tempict ${ }_{\text {ict }}=\mathrm{b}_{0}+\mathrm{b}_{1} *$ Youth $_{\text {ict }}+\mathrm{b}_{2} *$ Edhigh $_{\text {ict }}+\mathrm{b}_{3} *$ Edmid $_{\text {ict }}+\mathrm{b}_{4} *$ Female $_{\text {ict }} *$ Youth $_{\text {ict }}$ $+\mathrm{b}_{5} *$ Female $_{\text {ict }} *$ Edhigh $_{\text {ict }}+\mathrm{b}_{6} *$ Female $_{\text {ict }} *$ Edmid $_{\text {ict }}+$ Youth $_{\text {ict }} *{ }_{\text {yc }}$ + Edhigh $_{\text {ict }}{ }^{*} \mathrm{C}_{\mathrm{e} 1 \mathrm{c}}+$ Edmid $_{\mathrm{ict}}{ }^{*} \mathrm{C}_{\mathrm{e} 2 \mathrm{c}}+\mathrm{b}_{7}$ Tempreform $_{\mathrm{ct}}+\mathrm{b}_{8}$ Permreform $_{\mathrm{ct}}+\beta_{\mathrm{i}}+\gamma_{\mathrm{t}}+\mathrm{v}_{\mathrm{ict}}$

In equation 1), Emp is a dummy variable indicating that one is currently employed, Female is a female indicator, Youth is an indicator for being 16-25 years old, $b_{y c}$ is a country-specific youth shift term, Tempreform and Permreform indicate the presence of a reform changing the regulation of temporary or permanent employment respectively, taking values of 0 for years before reforms, 1 for years in which liberalizing reforms are in place, and -1 for years in which more restrictive reforms are in place, $\alpha$ is an individual fixed effect, $\phi$ is a time effect, and $\mathrm{u}$ is a disturbance term. ${ }^{7}$ In equation 2), the additional variables are Edhigh, which is a dummy for tertiary level of schooling (highest); Edmid, a dummy for middle levels of schooling (upper secondary), where primary and lower secondary education comprise the omitted category; $\mathrm{c}_{\mathrm{yc}}$, $\mathrm{C}_{\mathrm{e} 1 \mathrm{c}}$, and $\mathrm{c}_{\mathrm{e} 2 \mathrm{c}}$ are country-specific shift terms for youth, high level of education, and middle level of schooling respectively, $ß$ is an individual fixed effect, $\gamma$ is a time effect, and $v$ is a disturbance term.

\footnotetext{
${ }^{7}$ For Finland, data on employment contract type are only available from 1996 onward, and as Table 1 shows, there were liberalizing reforms to Finland's permanent regulations in 1996 and 2001. I therefore set the Permreform variable equal to zero for all years before the 2001 reforms, since the only before-after experiment available in the data are for the pre-2001 years vs. 2001.
} 
Equations 1) and 2) attempt to estimate the impact of EPL reforms on employment and temporary employment, respectively. The key reform variables allow for either liberalizing or more restrictive reforms to have effects, as suggested by Table 1 . The definitions of these two variables in effect permit us to compare outcomes under less restrictive vs. more restrictive rules on permanent or temporary jobs. Specifically, within each country, Table 1 shows that Tempreform takes on only at most two values: (0 or 1$)$ or $(0$ or -1$)$, with a similar pair of possibilities for Permreform. Previous theoretical research (Blanchard and Landier 2002) suggests that what influences the incidence of temporary employment is the strength of permanent employment protection relative to temporary employment protection, while equations 1) and 2) enter these two variables separately. This specification of course allows one to test this hypothesis, which implies that:

3) $b_{7}+b_{8}=0$.

An additional reason for entering the temporary and permanent reform variables separately is that they are qualitative: even under Blanchard and Landier's (2002) theory, they need not have effects with the same magnitude, if permanent employment protection reforms on average lower the cost of firing workers from permanent jobs by more than temporary employment reforms lower the cost of offering temporary jobs. Moreover, in only one country (Spain) do we observe reforms of both temporary and permanent employment regulations.

The other explanatory variables in equations 1) and 2) are included in order to control for demographic influences on employment outcomes. Because of the inclusion of individual fixed effects, only time-varying controls are included. Thus, effects of being a woman or an immigrant are subsumed in the person effect as are their interactions with country. However, as discussed further below, I estimate models separately by gender, nativity status, age, and education, as well as the pooled model. The specification of the basic pooled model in each case allows for country-specific effects of the time-varying demographic variables, as well as female 
interactions with the time-varying demographic variables, producing a relatively flexible functional form. However, in the employment equation, I do not include education. This is the case, since these equations will be estimated using individual fixed effects, and changes in schooling levels are endogenous with respect to employment. The specification in equation 1) in effect allows the policies to influence employment through schooling decisions. Note that I also do not include industry or occupation in the temporary employment equation. This decision was based on the fact that for some countries these variables are not available. In addition, the industry and occupation structure can be affected by employment regulations including EPL, suggesting again that these variables are endogenous. Excluding them allows one to estimate the full effects of EPL reforms.

As noted, equations 1) and 2) will be estimated using individual fixed effects models. In particular, each variable is expressed as the deviation from its person-specific mean. Thus, the individual fixed effect drops out of each equation. However, because it is possible to acquire more schooling and because age changes over time, main effects for these variables (in deviations from the mean) appear in the fixed effects models. In addition, using individual deviations from the mean also in effect eliminates any country-specific effects on employment levels or the incidence of temporary employment. But, as discussed above, countries may enact reforms in response to ongoing developments in their labor markets. To account for such effects, I also include in some models a set of country-specific trends. These models are less likely to suffer from endogeneity biases than models without these trends. Moreover, it is possible that the country trends include the possible effects of growing sentiment for reforms of the EPL system, which may have direct effects on the creation of temporary jobs. Their inclusion therefore allows one to estimate the pure effect of changing the law, controlling for these sentiments. Note that the country specific trend in the fixed effects model appears as the deviation of the country trend from its country mean. Further, each observation is weighted using the ECHP sampling weights, which I have adjusted so that each country receives the same total weight. Finally, standard errors are clustered at the country level. 
The basic specification in equations 1) and 2) forces the reforms to have the same effect

for all types of workers. However, previous research indicates that employment protection on permanent jobs is associated with a relatively greater incidence of temporary employment for youth, women, immigrants, and the less skilled (Kahn 2007). To account for this possibility, I also estimated these equations separately for youth (age 16-25), adults (age 26-65), men, women, immigrants, natives, those with the lowest (primary) level of schooling, and those with above primary schooling levels. To the extent that employment protection has a larger effect on the less experienced and less skilled (as argued both theoretically and empirically in Kahn 2006 and 2007), we would expect larger effects of reforms for youth, women, immigrants and those with low education levels.

\section{Descriptive Patterns and Regression Results}

\section{A. Descriptive Patterns}

Table 2 contains descriptive information on the incidence of employment and temporary employment for the countries studied here. The employment-population ratio is relatively high in the UK, the Netherlands and Portugal, while it is low in Italy and Spain. In order to assess the representativeness of the ECHP data with respect to the incidence of employment, I computed the correlation coefficient of each country's employment-population ratio with the corresponding 1999 figure from the OECD (2002, p. 55-56). Across the nine countries studied here, the two employment rates are very highly correlated at 0.97 , with a significance level (based on a simple regression) of better than the 0.001 level on a two tailed test, despite the small number of observations. Thus, the ECHP data appear to be representative with respect to the incidence of employment.

Table 2 also shows a very high incidence of temporary employment in Spain, with relatively high levels in Finland and Portugal; in contrast, the Netherlands and the UK have low levels of temporary jobs in these data. As was the case for overall employment, the ECHP data 
on temporary employment appear to match up well with OECD figures. Specifically, the OECD (2002) reported the incidence of temporary employment by gender, and Appendix Table A1 compares temporary employment for the ECHP and the OECD, both stratified by gender. It should be pointed out that the OECD’s definition of temporary employment differs from the ECHP's. Recall that in the ECHP, temporary employment refers to having a fixed duration employment contract. In contrast, the OECD definition of temporary work includes those on fixed term contracts, temporary agency workers, daily workers, trainees, people in job creation schemes, workers on contracts for a specific task, those on replacement contracts, and on-call workers (OECD, 2002, pp. 170-171). Not surprisingly, the incidence of temporary employment is higher in the OECD than in the ECHP, likely due at least in part to the OECD's more expansive definition. Despite this difference in definition, the OECD's and ECHP's measures in Table A1 are very highly correlated. In particular, for men, the two measures of temporary employment have a correlation coefficient of 0.88 , while for women the correlation is 0.90 . In addition, these correlations are each significant at the 0.001 level. Overall, the close correspondence for the OECD and ECHP employment and temporary data gives us some confidence that the ECHP data have some validity.

Table 3 shows the incidence of employment and temporary employment by country before and after each of the four reform types that occurred during the 1996-2001 period. Looking first at employment, the Table shows that its incidence was significantly higher in each case after reforms than before reforms. The size of the before-after contrast ranges from 1.1 to 7.9 percentage points, or 2.0 to 15.8 percent of the before-reform incidence of employment. The fact that employment was higher after each type of reform may seem contradictory, since this pattern holds regardless of the direction of the reform. This seeming anomaly suggests that there are likely to be ongoing employment trends within each country that may be confounded with the enactment of reforms.

In contrast to the employment patterns, the incidence of temporary employment shown in Table 3 seems highly consistent with one's expectations about impact of reforms on the 
incidence of temporary jobs. Specifically, in every case except one (the Netherlands), the incidence of temporary employment rises after enactment of reforms reducing restrictions on their use or reforms raising the cost of firing workers from permanent jobs; moreover, the incidence of temporary jobs falls in each case after enactment of reforms increasing restrictions on the use of temporary contracts or lowering firing costs from permanent jobs. The positive changes range from 4.8 to 30.7 percent of the pre-reform mean, while the negative changes have a range of -5.8 to -22.7 percent of the pre-reform mean. In addition, in most cases ( 7 of 10$)$, the changes are significant at better than the $6 \%$ level. Thus, Table 3 suggests that employment protection reforms may in general have had their expected effects on temporary employment. Of course, before making such a conclusion, we need to control for other influences, and this is done in the regression tables to which I now turn.

\section{B. Regression Results: Pooled Country Sample}

Table 4 shows individual fixed effects regression results for the determinants of employment incidence. Each coefficient refers to the impact of making regulations more lenient. Beginning with the results not controlling for country trends in employment, I find no significant effects of easing restrictions on the use of temporary employment contracts. However, reducing firing costs from permanent jobs is significantly positively associated with employment overall and has a positive coefficient for each subgroup that is significant with one exception (youth). The point estimates of these positive effects are moderate, ranging from 2-3 percentage points and from 2.9-7.4\% of the mean employment rate. Thus, the estimates not controlling for country trends in employment imply that relaxing protections on permanent jobs creates jobs on net. However, when one controls for country trends, as shown in Table 4, there is little evidence that on average in these nine countries, either type of reform has any impact on the probability of employment. Specifically, relaxing restrictions on temporary contracts continues to have insignificant effects on employment that are small in absolute value, and the effects of reducing firing costs from permanent jobs are also now in all cases except for immigrants negative, 
insignificant and small in absolute value. For immigrants, relaxing protections on permanent jobs has a negative employment effect that is significant at the $12 \%$ level.

Overall, comparing the employment results with and without country trends suggests that countries are most likely to relax protections on permanent jobs when employment is expanding. Thus while there is a positive within-person association between the probability of employment and the enactment of such reforms, the effect largely disappears when I control for country trends. The true average causal effect of the reforms on employment appears to be very small, possibly reflecting offsetting influences on separations and accessions; in addition, the aggregate effects shown in Table 4 could mask actual offsetting effects across the individual countries, and below, I present some evidence consistent with this possibility. Moreover, the positive association between liberalizing reforms and employment trends suggests a political outcome in which objections to reduced protection become weaker during expanding economies. This view would clearly characterize those who held permanent jobs at the time the reforms were enacted: the value these workers place on protection presumably falls the more secure they believe their jobs are. Possibly counteracting this group are those either out of work or in temporary jobs. They have an interest in generating more permanent work, and relaxing protection may be seen by them as a way of generating such jobs. However, when the economy is expanding, these individuals likely perceive a greater probability of obtaining permanent work on their own without reforms, and thus the value of the reforms in generating permanent jobs may be less for them during an expansion. The fact that I observe overall that liberalizing reforms occur during expanding economies suggests that the preferences of the incumbent workers in permanent jobs have the larger influence on reforms.

Table 5 shows results for the impact of EPL reforms on the incidence of temporary employment among wage and salary workers. The results without controlling for country trends appear to be very strong, with liberalizing reforms of temporary jobs raising the incidence and reducing protections of permanent jobs lowering the incidence of temporary employment. The results are usually statistically significant and are large relative to the incidence of temporary 
jobs. For example, the results for temporary job reforms show an increase of temporary employment of 1.4 to 3.4 percentage points, or 10.7 to 23.0 percent of the mean. The findings for permanent job reforms are even larger in magnitude (although in each case we accept the hypothesis that the effects of temporary and permanent protection reforms are equal in magnitude and opposite in sign) and are negative, as expected. They range from -2.8 to -5.1 percentage points or -24.3 to -37.5 percent of the mean. Moreover, the point estimates for the impact of permanent employment reforms show absolute effects that are larger in magnitude for youth, women, immigrants, and the less-skilled, relative to adults, men, natives and more skilled workers, respectively. ${ }^{8}$ This pattern is similar to that in earlier work using cross-sectional data (Kahn 2007). And, easing restrictions on temporary jobs has a larger effect on youth relative to adults as well, although again, this difference is not statistically significant.

While Table 5's results not controlling for country-specific trends appear to indicate important effects of both kinds of reforms on the incidence of temporary work, the Table shows that when one controls for these trends, only the results for temporary job reforms remain; even in this case, the impact of these reforms is much smaller than when country trends are excluded from the equation. Easing restrictions on the use of temporary employment contracts still has a significantly positive impact on the incidence of temporary employment overall, although the effect is now 0.55 percentage points (about 5 percent of the mean), compared to 2.2 percentage points not controlling for country trends. Moreover, the point estimate continues to be larger for youth than adults, but the effect for youth is smaller than its standard error. The effects of easing permanent employment protections are now all statistically insignificant and much smaller in magnitude than when I don't control for country trends. The reduction in the effects of reforms when country trends are included has the following implications. It appears that countries liberalizing their permanent employment protection systems do so in response to increasing incidence of permanent jobs. Moreover, liberalizing the use of temporary contracts appears to happen when their use is rising. The underlying trend in the relative use of temporary contracts

\footnotetext{
${ }^{8}$ These intergroup differences are not statistically significant, however.
} 
may reflect employer desires for flexibility and can also influence the preferences of different constituencies of workers — those in permanent jobs, temporary jobs or not employed—over changes in the reforms. As discussed by Brügemann (2007), these preferences can be difficult to sign and aggregate. But it does seem likely that workers currently in permanent jobs will be less resistant to loosening protections if they anticipate more abundant permanent employment opportunities in the future.

Combining the results in Tables 4 and 5 with controls for country trends suggests the following conclusion. Reforms of the permanent employment protection systems have not had in the aggregate of the countries considered here causal effects on either overall employment or the relative incidence of permanent jobs. While reforms making it easier to create temporary jobs have not on net raised employment, they have increased the share of jobs that are temporary. Perhaps these latter reforms in effect encourage firms to substitute temporary jobs for permanent jobs.

\section{Regression Results: Separate Estimates by Country}

While the pooled sample may allow us to draw some general conclusions about the average effect in Europe of reforms of employment protection systems, additional insight into the impact of reforms can be obtained by studying the incidence of employment and temporary jobs separately by country. Since the reforms were not identical across countries, it is possible that their effects varied as well. In addition, the aggregated models assume that liberalizing reforms have an effect that is of the same magnitude (but opposite in sign) as reforms that increase restrictions. Estimating models separately by country allows us to relax this assumption, since each country reformed its temporary employment or permanent employment regulations in only one direction during the 1996-2001 period. Tables 6 and 7 show the impact of reforms on employment and temporary jobs among wage and salary workers respectively, separately by country, with a trend included for each country. First, Table 6 shows that reforms expanding the use of temporary contracts have a negative impact on employment in five of the 
six countries where temporary employment reforms have taken place. In two of these cases, the effect is significant (Italy and Spain), and for Spain, recall that the direction of the reform was for more restricted use of temporary contracts. Evidently the Spanish reform raised employment, all else equal. The negative findings are consistent with Blanchard and Landier’s (2002) reasoning that, since the exit rate is higher from temporary than permanent employment, anything that raises the incidence of temporary jobs may raise the overall exit rate from employment. ${ }^{9}$

Second, Table 6 also shows heterogeneous effects of permanent employment protection reforms on employment, with three significant negative effects and one significant positive effect. Recall our earlier discussion on the theoretical ambiguity about the impact of these reforms on employment and temporary employment. The negative effects shown in Table 6 suggest that in the countries liberalizing their systems (Finland and Spain), the short run impact of liberalizing permanent employment protection reforms, in which firms may be encouraged to discharge marginal workers, may dominate. In France and the UK, reforms increased protections, leading to an increase in French employment and a decrease in employment in the UK. Again, the French result is likely to be a short-run effect, since the reform evidently deterred some firms from firing permanent workers. In the UK, the fact that the reforms appeared to lower employment suggests a longer-term response involving reduced permanent job creation due to the higher firing costs.

Table 7 shows results for the effects of reforms on the incidence of temporary jobs among wage and salary workers, separately by country. First, liberalizing the use of temporary contracts raises the incidence of temporary jobs in five of six cases, with four of the five effects significant and the fifth (Spain, for which the direction of the reform was to increase restrictions on temporary contracts) about 1.3 times its standard error. Thus, the aggregate finding reported in Table 5 appears to hold generally. Liberalizing the use of temporary contracts raises the

\footnotetext{
${ }^{9}$ Indeed, as discussed below, my analysis of transitions finds that the transition rate to nonemployment is much higher from temporary jobs than from permanent jobs.
} 
incidence of temporary jobs even after accounting for individual fixed effects and country trends. Second, reducing the protections on permanent jobs has positive effects on temporary employment in three cases, with two of these effects (France and Spain) significant, and reduces the incidence in one case (Finland), again with a significant effect. As shown in Table 5, the average impact across the countries is an insignificant negative effect on temporary employment. But Table 7 shows that this result hides the diverse effects across countries. The positive effects are consistent with the idea that reducing permanent employment protections raises exits from permanent jobs and increases employment in temporary jobs. The negative effect for Finland appears inconsistent with the negative impact I found for employment (Table 6). However, Finland's protection reforms also occurred at the same time as other reforms raising the relative cost of part-time workers (Hietenan 2001), which could have reduced both employment and the incidence of temporary jobs, to the extent that part-time workers are more likely to be in temporary jobs.

The separate analyses by country suggest a robust positive effect on temporary employment contracts of reforms easing restrictions on their use but some more heterogeneous effects of permanent protection reforms. The latter perhaps reflects the tension between short run incentives to lay workers off and long run incentives for job creation. We can obtain some evidence on the short run effects by examining the impact of reforms on transitions from permanent jobs into the possible labor market states defined here-nonemployment, permanent employment, and temporary employment. To study this issue, one needs to compare transitions before reforms with transitions after reforms. Since Table 1 shows that Germany and Portugal both had reforms in 1996, it is not possible to observe transitions before reforms for these two countries (because the ECHP didn’t begin collecting data on contract type until 1995). I therefore analyze transitions for the other seven countries for which one can observe transitions both before and after protection system reforms. I note that the basic pooled regression results 
for these seven countries were very similar to those reported in Tables 6 and 7, which were based on the full sample of nine countries. ${ }^{10}$

Table 8 shows individual fixed effects regression results for transitions from permanent jobs. The models in effect examine the impact of reforms on the propensity of the same individual to make the indicated transitions, controlling for aging and country-specific trends. The most striking results concern the impact of liberalizing permanent protection reforms. In three of the four countries experiencing reforms of their permanent employment protection regulations (France, Spain, and the UK), the regressions indicate that making regulations more liberal raises the incidence of transitions out of permanent employment and into nonemployment, with each effect being highly significant. ${ }^{11}$ Moreover, the effects on transitions to temporary jobs are small in magnitude and statistically insignificant. The net result is that liberalizing protections on permanent jobs contributes to joblessness and to a relative increase in the incidence of temporary employment among workers for these countries. These transitions are thus consistent with the short run effects of such reforms in which firms are encouraged to lay off marginal workers. In Finland, in contrast, such reforms appear to increase the retention rate in the permanent job sector, perhaps indicating that the job creation effect is relatively quick there. However, as mentioned earlier, there were confounding reforms in Finland that limit our ability to make strong conclusions about the effect of employment protection reforms.

Table 8 indicates that a more liberal regime for creating temporary jobs raises transitions from permanent work into joblessness in three cases (Belgium, Italy and Spain). This result suggests perhaps that such reforms encourage the substitution of temporary for permanent jobs, with the accompanying higher exit rate from temporary employment, as emphasized by

\footnotetext{
10 Specifically, in the pooled seven country models with country trends, liberalizing temporary employment raised the incidence of temporary jobs with an effect of 0.0089 (with standard error 0.0021 ), while liberalizing reforms of permanent job protections had a negative impact on temporary employment of -0.0010 (with standard error 0.0028 ). The impact of reforms on overall employment continued to be insignificant and small in magnitude: permanent employment reforms had a coefficient of -0.0071 (with standard error 0.0075), while temporary employment reforms had an effect of -0.0053 (with standard error 0.0064 ).

${ }^{11}$ Recall that the reforms in France and the UK raised the costs of discharging workers, so the reforms in these cases actually lowered the transition probability out of permanent jobs.
} 
Blanchard and Landier (2002). ${ }^{12}$ In two of these cases (Belgium and Italy), temporary employment reforms raise transitions to temporary employment relative to permanent employment, providing partial support for this view.

The findings in Tables 6-8 suggest that in the ECHP data, which of course cover only a six year period, the short run effects of moreliberal rules for firing workers from permanent jobs (which lead to higher rates of firing) tend to dominate any possible long-term job creation effects. Is there evidence from transitions that such long term effects may exist? Specifically, if reforms eventually lead firms to open up more permanent jobs after redesigning their employment systems, we might expect to see that liberalizing reforms of permanent employment protection increase workers' transition rates from nonemployment or temporary employment into permanent jobs. Moreover, if as Blanchard and Landier (2002) argue, firms create temporary jobs first before they are made permanent, we could also expect to see reforms raise the transition rate from nonemployment into temporary jobs. However, even in the short run, if reforms increase the exit rate from permanent jobs, this could open up replacement opportunities. Thus, transitions from nonemployment or temporary jobs to permanent jobs, while suggestive of some possible long term responses to reforms, could still represent the effects of short term replacement decisions. But the absence of an effect of reforms on such transitions would suggest that the long run effect hasn't occurred yet. It is therefore of interest to examine the net effect of these forces on the propensity of the nonemployed or those in temporary jobs to move to employment or permanent jobs.

I present some evidence relevant to these questions in Tables 9 and 10, where I estimate the impact of reforms on transitions from nonemployment (Table 9) and from temporary jobs (Table 10). First, Table 9 shows that liberalizing reforms of systems of protection for permanent jobs have diverse effects on transitions from nonemployment to employment. On the one hand,

12 Across the seven countries for which I analyze transitions, the average transition rate out of temporary jobs into nonemployment was 0.195 , in contrast to only 0.046 for transitions from permanent jobs to nonemployment (where each country is equally weighted). Note that a transition is defined as a year-to-year change, perhaps hiding some within-year transitions (for which the ECHP doesn’t have data on contract type). 
in Spain and the UK, reducing firing costs from permanent jobs brings people into work, an effect perhaps expected given Table 8's results showing positive effects of such reforms on transitions from permanent jobs to nonemployment. We could be observing the increased churning such reforms are said to produce (Bertola 1999). On the other hand, these reforms appear to lower workers' transition probability from nonemployment to jobs in Finland and in France. As Table 6 indicated, in these two countries, liberalizing reforms lowered overall employment, and Table 9 provides little evidence of job creation or replacement of discharged workers induced in these countries. Within these countries reducing permanent employment protections had effects on transitions from nonemployment to permanent or to temporary jobs that went in the same, negative direction. In the case of Finland, contemporaneous policy changes raising the cost of part-time workers could reduce individuals' transitions out of joblessness, perhaps also explaining that country’s results in Table 9. Second, making temporary jobs easier to offer significantly raised the incidence of transitions from nonemployment to temporary jobs in Italy, the Netherlands, and Spain, with a small and insignificant negative effect for Belgium. The net effect on transitions to overall employment was significantly positive in Italy and Spain, with insignificant effects for Belgium and the Netherlands. The positive effects on transitions to employment could reflect increased churning as well as a longer run response of job creation.

Finally, Table 10 shows transitions from temporary jobs. One might expect reforms liberalizing the use of temporary contracts to lower transition rates from temporary to permanent jobs. In contrast, reducing permanent job protection is expected to raise such transition rates by lowering the productivity standard needed to insure promotion into a permanent job (Blanchard and Landier 2002). Table 10 shows mixed support for such predictions. On the one hand, making it easier to create temporary jobs raises the incidence of staying in such jobs in the Netherlands and Spain, as expected; on the other hand, we observe the opposite results in Belgium and Italy. Reducing for permanent employment protection significantly raises 
transitions from temporary work to permanent work in Spain and the UK, as expected; however, effects were insignificant in Finland and France.

Overall, this analysis of transitions has suggested that lowering firing costs from permanent jobs raises exit rates from such jobs, as expected. However, there is also some evidence that such reforms raise workers' transitions from temporary to permanent jobs and also some limited evidence that such reforms bring people into work from out of work. Making temporary jobs easier to create also brings people into employment (largely temporary) from out of work but also in some cases lessens the incidence of transitions out of temporary to permanent jobs. Given the short time period analyzed, these are likely to be largely short run effects. The net effect of these transitions is the full short run effect of reforms on the incidence of employment or temporary employment among wage and salary workers.

We have seen in Table 7 that making temporary jobs easier to create raises the incidence of such jobs in almost all cases. Reducing permanent employment protection appears in most cases to raise the relative incidence of temporary jobs, likely reflecting the short run effects on exits from permanent jobs. In contrast, earlier research has found that cross sectional differences in the strictness of permanent employment regulation are positively associated with differences in the incidence of temporary work (Booth, Dolado and Frank 2002), suggesting that in the long run, liberalizing employment protection systems may create permanent jobs. Of course, a major difficulty with such cross-sectional comparisons is that there may be confounding factors associated with these policies, producing potentially biased results. However, cross-country differences in permanent employment protection are typically more dramatic than within-country changes over time, suggesting that cross-country comparisons provide greater variation in the key explanatory variable (permanent protection regulations) and thus a potentially more powerful test than within-country studies over time. For example, using data from the OECD (2004), for the three periods comprising the late 1980s, 1990s and 2003, for the nine countries studied here, I find that the between-country variance in the OECD’s permanent job protection index accounts for $91 \%$ of the total (pooled cross-section and time-series) variance in the index, 
with within-country changes accounting only for 9\%. Interestingly, changes in temporary job regulation are more dramatic, and the within country variance accounts for fully $40 \%$ of the total. Thus, my within-country design may be more powerful for the temporary reforms, and I indeed obtain the most robust findings for them with respect to the incidence of temporary jobs.

\section{Conclusions}

This paper has used longitudinal data on individuals from the ECHP for nine countries over the 1996-2001 period to investigate the impact of reforms of employment protection systems on the incidence of employment and of temporary jobs for wage and salary workers. Important features of the research design included the use of individual fixed effects models as well as the inclusion of country-specific trends in the dependent variable. Both the possibly changing labor force composition as well as the possible endogeneity of the reforms are at least partially addressed by these design features. In particular, I observe employment outcomes for the same individuals under different laws, and I control for changes in employment or temporary employment that could directly affect legislatures’ willingness to enact reforms.

A basic finding that is robust to all specifications and to the disaggregation of the sample by country is that policies making it easier to create temporary jobs raise the likelihood that wage and salary workers will be in temporary jobs. However, there is no evidence that such reforms raise employment, and in some countries, they appear to lower employment. Thus, these reforms, while touted as a way of jump-starting individuals' careers in the job market appear rather to encourage a substitution of temporary for permanent work.

Regarding the impact of reforms of permanent employment protection mandates, not controlling for country-specific trends, reducing restrictions on firing workers from permanent jobs appears to raise employment and to raise the incidence of permanent work among the employed, as the reforms were intended to do. However, these effects become small and insignificant when I control for country-specific trends. The impact of controlling for country- 
specific trends suggests that countries are most likely to enact reforms liberalizing their permanent job protection regulations when the incidence of employment and permanent employment is rising. Moreover, when I disaggregate by country, such reforms appear more often to lower overall employment and to lower the share of employment in permanent jobs. These are likely to reflect short run impacts of such reforms, which make it easier for firms to discharge substandard workers. These findings may be contrasted with international crosssectional research in which the strength of permanent employment protections is negatively correlated with the employment share in permanent jobs (Booth, Dolado and Frank 2002). These latter findings may reflect the long run effects of such protections, which include lower levels of permanent job creation. 


\section{Appendix: The Impact of Firing Costs from Permanent Jobs on Promotion from Temporary Jobs and Retention in Permanent Jobs}

In this Appendix, I illustrate the predictions mentioned in the text that reducing firing costs from permanent jobs will raise promotion rates from temporary jobs and also raise exits from permanent jobs. Assume that in the sector potentially offering permanent jobs, and following Blanchard and Landier (2002), firms initially place workers into a temporary job and await a productivity observation $\mathrm{y}_{1}$; I assume that $\mathrm{y}_{1}$ is uniformly distributed between 0 and 1 . If the worker is promoted, the firm will at some future point observe productivity $\mathrm{y}_{2}$, which I assume again will be uniformly distributed, with support $\left(y_{1}, 1\right)$. If the worker is retained in the permanent job after the observation of $y_{2}$, there will eventually be a third productivity observation $\mathrm{y}_{3}$, which again is uniformly distributed, with support $\left(\mathrm{y}_{2}, 1\right)$. One can view these productivity assumptions as a case where upon promotion or retention, the worker will raise his/her productivity through learning by doing, and the increase is stochastic. Suppose that wages given the permanent job are fixed at w (although allowing wage bargaining as in Blanchard and Landier (2002) would not change the qualitative implications, at least if workers do not appropriate the entire firing cost as higher wages). And assume for convenience that firms break even on workers while they are in temporary jobs. Finally, suppose for simplicity that there is no discounting and that the price of output is fixed at 1.

Under these assumptions, we can analyze the impact of firing costs c on promotion and retention. Begin recursively with the decision to retain workers in their permanent jobs after the realization $\mathrm{y}_{2}$ of their productivity observation. The firm will choose a reservation productivity level $\mathrm{y}_{2}{ }^{*}$, at which it is indifferent between retaining and firing the worker. Thus,

(A1) $\mathrm{E}\left(\mathrm{y}_{3} \mid \mathrm{y}_{2}=\mathrm{y}_{2} *\right)-\mathrm{w}=-\mathrm{c}$. 
The left hand side of (A1) is the expected third period profit given retention and a second period productivity realization equal to the threshold $\mathrm{y}_{2}{ }^{*}$, while the right hand side is the profit given firing. Under the assumption of a uniform productivity distribution, we have:

(A2) $0.5 *\left(\mathrm{y}_{2}^{*}+1\right)-\mathrm{w}=-\mathrm{c}$, or

(A3) $\mathrm{y}_{2} *=2(\mathrm{w}-\mathrm{c})-1$.

Thus, lowering c raises the retention threshold. We should observe an increase in transitions out of permanent jobs when firing costs are lowered. In addition, even allowing wages to vary (as in Blanchard and Landier (2002), workers may appropriate a portion of the firing costs), as long as they change by less than firing costs, we will observe an increase in such transitions. This condition will hold, for example, in Nash bargaining models.

Next, consider the firm's choice at the end of the probationary period, where it receives an observation on $\mathrm{y}_{1}$. The firm will choose a reservation productivity threshold $\mathrm{y}_{1}$ * such that it will be indifferent between promoting the worker and releasing him/her (at zero firing cost in this model). Under these assumptions:

(A4) $\mathrm{E}\left(\prod \mid \mathrm{y}_{1} *\right)=0 * \mathrm{P}\left(\mathrm{y}_{1}<\mathrm{y}_{1} *\right)+\mathrm{P}\left(\mathrm{y}_{1}>=\mathrm{y}_{1} *\right)\left\{\left[\left(\mathrm{E}\left(\mathrm{y}_{2} \mid \mathrm{y}_{1}>=\mathrm{y}_{1} *\right)-\mathrm{w}\right]+\right.\right.$ $\mathrm{E}\left[\mathrm{P}\left(\mathrm{y}_{2}>=\mathrm{y}_{2} * \mid \mathrm{y}_{1}>=\mathrm{y}_{1} *\right)\right]\left(\left(\mathrm{E}\left(\mathrm{y}_{3} \mid \mathrm{y}_{2}>=\mathrm{y}_{2} *\right)-\mathrm{w}\right)+\right.$ $\left.\mathrm{E}\left[\mathrm{P}\left(\mathrm{y}_{2}<\mathrm{y}_{2} * \mid \mathrm{y}_{1}>=\mathrm{y}_{1} *\right)\right](-\mathrm{c})\right\}$,

where $\prod$ is profit.

In (A4), the choice of $\mathrm{y}_{1} *$ influences profits by influencing the probability of continuing the employment relationship into the second and third periods and the expected productivity in the second period. Since the choice of $\mathrm{y}_{2} *$ is independent of $\mathrm{y}_{1} *$ (see equation (A3)), (A4) can be maximized simply by choosing the optimal $\mathrm{y}_{1} *$ subject to the optimal $\mathrm{y}_{2} *$. Moreover, the independence of $\mathrm{y}_{2} *$ and $\mathrm{y}_{1} *$ implies that third period productivity conditional on retention does not depend on $\mathrm{y}_{1}{ }^{*}$. In addition, embedded in equation (A4) is the assumption of zero firing costs from temporary jobs. 
In order to determine the impact of firing costs $\mathrm{c}$ on the promotion standard $\mathrm{y}_{1}{ }^{*}$, it is sufficient to note that, assuming an interior solution for $\mathrm{y}_{1} *$ :

(A5) $\prod_{\mathrm{y} 1 *}=0$

at an optimum, where the subscript on $\prod$ signifies a partial derivative assuming $\mathrm{y}_{2} *$ is at its optimum and assuming there are no corner solutions for $\mathrm{y}_{1} *$. Therefore,

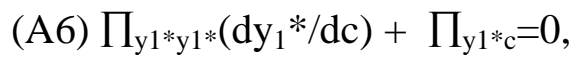
where the double subscripts signify second order partial derivatives. Since the second order

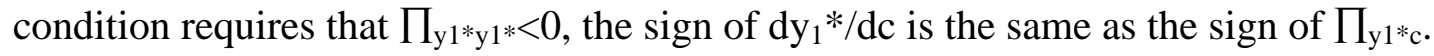

Rewriting equation (A4), we have:

(A7) $\mathrm{E}\left(\Pi \mid \mathrm{y}_{1} *\right)=\left(1-\mathrm{y}_{1} *\right)\left\{\left[.5\left(1+.5\left(\mathrm{y}_{1} *+1\right)\right)-\mathrm{w}\right]+\right.$ $\left.\mathrm{E}\left[\left(1-\mathrm{y}_{2} *\right) /\left(1-\mathrm{y}_{1}\right) \mid \mathrm{y}_{1}>=\mathrm{y}_{1} *\right)\right]\left(.5\left(.5\left(\mathrm{y}_{2} *+1\right)+1\right)-\mathrm{w}\right)+$ $\left.\left.\left(1-\mathrm{E}\left[\left(1-\mathrm{y}_{2} *\right) /\left(1-\mathrm{y}_{1}\right) \mid \mathrm{y}_{1}>=\mathrm{y}_{1} *\right)\right]\right)(-\mathrm{c})\right\}=$ $\left(1-\mathrm{y}_{1} *\right)\left\{\left[.5\left(1+.5\left(\mathrm{y}_{1} *+1\right)\right)-\mathrm{w}\right]+\right.$ $(2-2 \mathrm{w}+2 \mathrm{c}) \mathrm{E}\left(\left(1 /\left(1-\mathrm{y}_{1}\right)\right) \mid \mathrm{y}_{1}>=\mathrm{y}_{1} *\right) * .5(1-\mathrm{w}-\mathrm{c})+$ $\left.[1-(2-2 \mathrm{w}+2 \mathrm{c})] \mathrm{E}\left(\left(1 /\left(1-\mathrm{y}_{1}\right)\right) \mid \mathrm{y}_{1}>=\mathrm{y}_{1} *\right) *(-\mathrm{c})\right\}=$ $\left(1-\mathrm{y}_{1} *\right)\left\{\left[.5\left(1+.5\left(\mathrm{y}_{1} *+1\right)\right)-\mathrm{w}\right]+\right.$ $\left.(2-2 \mathrm{w}+2 \mathrm{c}) \mathrm{E}\left(\left(1 /\left(1-\mathrm{y}_{1}\right)\right) \mid \mathrm{y}_{1}>=\mathrm{y}_{1} *\right) *[.5(1-\mathrm{w}+\mathrm{c})]-\mathrm{c}\right\}$ $\equiv\left(1-\mathrm{y}_{1} *\right) \mathrm{g}\left(\mathrm{y}_{1} *, \mathrm{c}\right)$, where $\mathrm{g}(-)$ is the expression in braces. ${ }^{13}$

Therefore, to determine the sign of $\mathrm{dy}_{1} * / \mathrm{dc}$, we need to sign:

(A8) $\partial^{2} \mathrm{E}\left(\Pi \mid \mathrm{y}_{1} *\right) / \partial \mathrm{y}_{1} * \partial \mathrm{c}=\left(1-\mathrm{y}_{1} *\right) \partial^{2} \mathrm{~g} / \partial \mathrm{y}_{1} * \partial \mathrm{c}-\partial \mathrm{g} / \partial \mathrm{c}$.

Since raising $\mathrm{y}_{1} *$ raises $\mathrm{E}\left(\left(1 /\left(1-\mathrm{y}_{1}\right)\right) \mid \mathrm{y}_{1}>=\mathrm{y}_{1} *\right)$ and since raising firing costs $\mathrm{c}$ reduces the expected profit given promotion to permanent jobs (so that $-\partial \mathrm{g} / \partial \mathrm{c}$ rises), we can infer that raising firing costs raises the initial hiring standard for promotion. Thus lowering firing costs for

\footnotetext{
${ }^{13}$ Here I have used the uniform distribution to infer, for example, that conditional on promotion (i.e. $\mathrm{y}_{1}>=\mathrm{y}_{1} *$ ), the second period productivity for a person with $\mathrm{y}_{1}$ is uniformly distributed over $\left(\mathrm{y}_{1}, 1\right)$; thus, the average second period

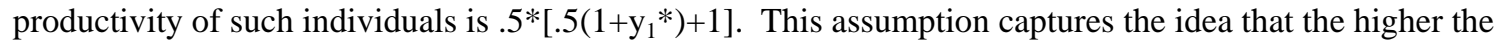
promotion standard, the higher future productivity is expected to be. In addition, the expression $\left[\mathrm{P}\left(\mathrm{y}_{2}>=\mathrm{y}_{2} * \mid \mathrm{y}_{1}>=\mathrm{y}_{1} *\right)\right]$ will equal 1 for those whose $\mathrm{y}_{1}=>\mathrm{y}_{2} *$. For these individuals, raising $\mathrm{y}_{1} *$ will not affect the probability of retention, but overall, $\partial^{2} \mathrm{~g} / \partial \mathrm{y}_{1} * \partial \mathrm{c}$ will still be positive since some retained workers will have $\mathrm{y}_{1} *<=\mathrm{y}_{1}<\mathrm{y}_{2} *$.
} 
permanent jobs will increase transitions out of permanent jobs as well as transitions from temporary jobs to permanent jobs. 


\section{References}

Autor, David H. and Susan N. Houseman, "Do Temporary Help Jobs Improve Labor Market Outcomes for Low-Skilled Workers? Evidence from Random Assignments,” working paper, MIT, October 2005.

Bertola, Giuseppe, “Microeconomic Perspectives on Aggregate Labor Markets,” in Orley Ashenfelter and David Card, eds., Handbook of Labor Economics, Volume 3C (Amsterdam: Elsevier, 1999), pp. 2985-3028.

Bertola, Giuseppe, Francine D. Blau and Lawrence M. Kahn, "Labor Market Institutions and Demographic Employment Patterns,” Journal of Population Economics 20, no. 4 (October 2007): 833-867.

Bertola, Giuseppe and Andrea Ichino, "Crossing the River: A Comparative Perspective on Italian Employment Dynamics,” Economic Policy 10, no. 2 (October 1995): 359-420.

Blanchard, Olivier and Augustin Landier, “The Perverse Effects of Partial Labour Market Reform: Fixed-Term Contracts in France,” Economic Journal 112, no. 480 (June 2002): F214-F244.

Boeri, Tito and Pietro Garibaldi, "Two Tier Reforms of Employment Protection: A Honeymoon Effect?” Economic Journal 117, no. 521 (June 2007): F357-F385.

Booth, Alison L., Juan J. Dolado and Jeff Frank, "Symposium on Temporary Work Introduction,” Economic Journal 112, no. 480 (June 2002): F181-F188.

Booth, Alison L., Marco Francesconi and Jeff Frank, “Temporary Jobs: Stepping Stones or Dead Ends,” Economic Journal 112, no. 480 (June 2002): F189-F213.

Brügemann, Björn, “Employment Protection: Tough to Scrap or Tough to Get?” Economic Journal 117, no. 521 (June 2007): F386-F415.

Holmlund, Bertil and Donald Storrie, “Temporary Work in Turbulent Times: The Swedish Experience,” Economic Journal 112, no. 480 (June 2002): F245-F269.

Hietanen, Juha, “New Employment Contracts Act in Force,” European Foundation for the Improvement of Living and Working Contitions, European Industrial Relations Observatory Online (EIRO), July 28, 2001, at http://www.eurofound.europa.eu/eiro/2001/07/feature/fi0107193f.htm, accessed November 1, 2007.

Kahn, Lawrence M., “The Impact of Employment Protection Mandates on Demographic Temporary Employment Patterns: International Microeconomic Evidence,” Princeton University Industrial Relations Section Working Paper No. 507, January 2006.

Kahn, Lawrence M., “The Impact of Employment Protection Mandates on Demographic Temporary Employment Patterns: International Microeconomic Evidence," Economic Journal 117, no. 521 (June 2007): F333-F356. 
Kugler, Adriana, “The Impact of Firing Costs on Turnover and Unemployment: Evidence from the Colombian Labour Market Reform," International Tax and Public Finance Journal 6, no. 3 (August 1999): 389-410.

Kugler, Adriana, Juan F. Jimeno, and Virginia Hernanz, "Employment Consequences of Restrictive Permanent Contracts: Evidence from Spanish Labor Market Reforms,” working paper, University Houston, January 2005.

Kugler, Adriana and Giovanni Pica, "Effects of Employment Protection on Worker and Job Flows: Evidence from the 1990 Italian Reform,” Labour Economics, forthcoming.

Marinescu, Ioana, "Shortening the Tenure Clock: The Impact of Strengthened UK Job Security Legislation,” working paper, University of Chicago, June 2007.

OECD, Employment Outlook: July 2002 (Paris: OECD, 2002).

OECD, Employment Outlook: 2004 (Paris: OECD, 2004).

Saint-Paul, Gilles, “The Political Economy of Employment Protection,” Journal of Political Economy 110, no. 3 (June 2002): 672-704. 
Table 1: Reforms in Employment Protection Systems, 1996-2001

\begin{tabular}{|c|c|c|}
\hline Country & $\begin{array}{l}\text { Year of } \\
\text { Reform }\end{array}$ & Description of Reform \\
\hline Belgium & 1997 & Restrictions on Temporary Work Agencies were reduced and Fixed Term Contracts were made renewable. \\
\hline \multirow[t]{2}{*}{ Finland } & 1996 & Mandatory notice period was reduced. \\
\hline & 2001 & Mandatory notice period was reduced further. \\
\hline France & 2001 & Severance pay entitlements were increased. \\
\hline Germany & 1996 & Allowable frequency and duration for Temporary Work Agency and Fixed Term Contracts were increased. \\
\hline \multirow[t]{4}{*}{ Italy } & 1997 & Fixed Term Contract use was liberalized. \\
\hline & 1998 & Temporary Work Agencies were allowed. \\
\hline & 2000 & Temporary Wage Agency use was extended and some restrictions for unskilled workers were lifted. \\
\hline & 2001 & Restrictions on the use of Fixed Term Contracts were further lifted. \\
\hline Netherlands & 1999 & Frequency of Fixed Term Contracts and duration of contracts with Temporary Work Agencies was increased. \\
\hline Portugal & 1996 & The use of Fixed Term Contracts and Temporary Work Agencies was widened. \\
\hline \multirow[t]{2}{*}{ Spain } & 1997 & Maximum compensation for unfair dismissal was reduced \\
\hline & 2001 & $\begin{array}{l}\text { Restrictions on the use of Fixed Term Contracts were } \\
\text { increased. }\end{array}$ \\
\hline $\begin{array}{l}\text { United } \\
\text { Kingdom }\end{array}$ & 2000 & $\begin{array}{l}\text { Trial period for protection against unfair dismissal was cut from two years to one } \\
\text { year. }\end{array}$ \\
\hline
\end{tabular}

Source: OECD (2004), pp. 119-120. 
Table 2: Mean Values for Employment and Temporary Employment, by Country, 1996-2001

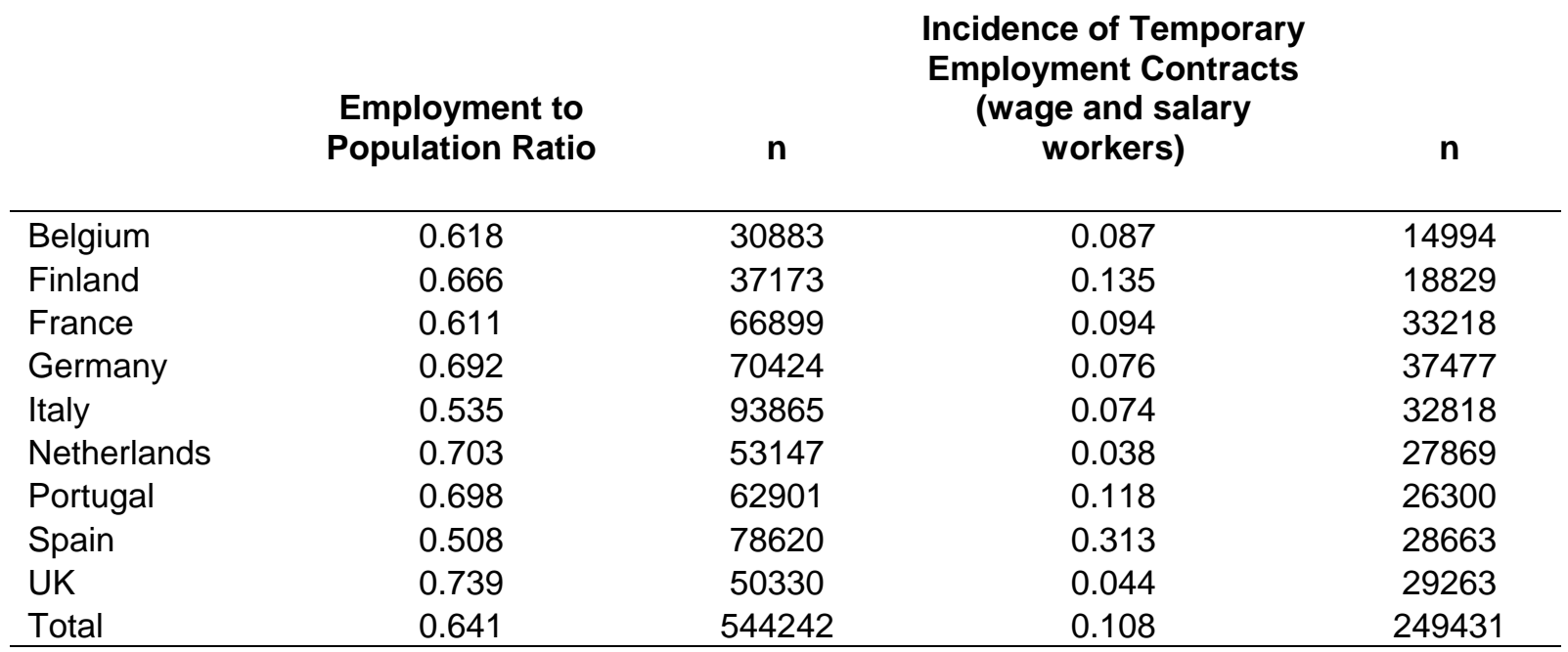

Source: European Community Household Panel (ECHP). Data are weighted by adjusting the ECHP's sampling weights so that each country receives the same total weight. 
Table 3: Employment to Population Ratios Before and After Employment Protection Reforms

\section{Employment-Population Ratios}

Temporary Employent Contract Incidence (wage and salary workers)

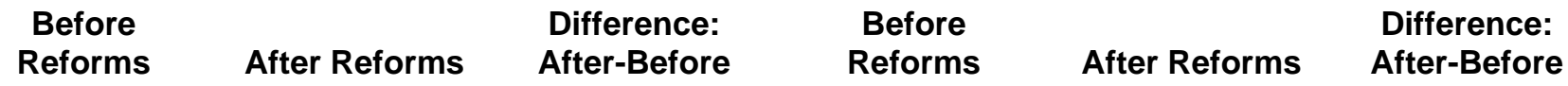

A. Countries Reducing Restrictions on Temporary Employment Contracts

\begin{tabular}{|c|c|c|c|c|c|c|}
\hline Belgium & 0.602 & 0.627 & 0.025 & 0.077 & 0.092 & 0.014 \\
\hline Germany & 0.680 & 0.694 & 0.014 & 0.073 & 0.077 & 0.004 \\
\hline Italy & 0.528 & 0.538 & 0.011 & 0.069 & 0.077 & 0.007 \\
\hline Netherlands & 0.680 & 0.735 & 0.054 & 0.043 & 0.033 & -0.010 \\
\hline Portugal & 0.679 & 0.702 & 0.023 & 0.106 & 0.121 & 0.014 \\
\hline
\end{tabular}

B. Countries Reducing Protections on Permanent Employment Contracts

$\begin{array}{lllllll}\text { Finland } & 0.661 & 0.701 & 0.041 & 0.136 & 0.128 & -0.008 \\ \text { Spain } & 0.480 & 0.522 & 0.042 & 0.331 & 0.306 & -0.025\end{array}$

C. Countries Increasing Restrictions on Temporary Employment Contracts
Spain
0.499
0.578
0.079
0.318
0.284
$-0.034$

D. Countries Increasing Protections on Permanent Employment Contracts

\begin{tabular}{lllllll} 
France & 0.608 & 0.627 & 0.019 & 0.093 & 0.100 & 0.006 \\
UK & 0.735 & 0.750 & 0.015 & 0.041 & 0.053 & 0.013 \\
\hline
\end{tabular}

Source: ECHP. Note all employment differences are significant at the $4.5 \%$ level or better (two-tailed tests). All temporary employment differences are signficant at the 5\% level or better on two tailed tests except for: Germany (51\%), Portugal (6\%), Finland (27\%), and France (17\%). Significance levels are based on regressions of the employment or temporary employment on the reform dummy variable, with standard errors clustered at the individual level. 
Table 4: Individual Fixed Effects Results for the Impact of Less Restrictive Protection on Employment

\section{Country Trends Excluded}

Effects of Reforms

\section{Country Trends Included}

\section{Effects of Reforms}

Mean of

Dependent Temporary Permanent Test:

Variable Employment Employment $b_{\text {perm }}+b_{\text {temp }}=0$ Sample Size

\begin{tabular}{|c|c|c|c|c|c|c|c|c|}
\hline All & $\begin{array}{c}-0.0062 \\
(0.0100)\end{array}$ & $\begin{array}{c}0.0260 \\
(0.0081)\end{array}$ & $p=.0883$ & 0.6412 & $\begin{array}{c}0.0014 \\
(0.0051)\end{array}$ & $\begin{array}{l}-0.0078 \\
(0.0079)\end{array}$ & $p=.4633$ & 544242 \\
\hline Youth & $\begin{array}{c}-0.0011 \\
(0.0206)\end{array}$ & $\begin{array}{c}0.0348 \\
(0.0351)\end{array}$ & $p=.5282$ & 0.4695 & $\begin{array}{c}0.0004 \\
(0.0160)\end{array}$ & $\begin{array}{l}-0.0137 \\
(0.0180)\end{array}$ & $p=.5785$ & 106247 \\
\hline Adults & $\begin{array}{l}-0.0040 \\
(0.0099)\end{array}$ & $\begin{array}{c}0.0197 \\
(0.0062)\end{array}$ & $p=.1799$ & 0.6807 & $\begin{array}{c}0.0007 \\
(0.0039)\end{array}$ & $\begin{array}{l}-0.0062 \\
(0.0064)\end{array}$ & $p=.4629$ & 437995 \\
\hline Men & $\begin{array}{l}-0.0086 \\
(0.0080)\end{array}$ & $\begin{array}{c}0.0231 \\
(0.0060)\end{array}$ & $p=.0985$ & 0.7351 & $\begin{array}{c}0.0029 \\
(0.0063)\end{array}$ & $\begin{array}{l}-0.0068 \\
(0.0084)\end{array}$ & $p=.7206$ & 265753 \\
\hline Women & $\begin{array}{l}-0.0039 \\
(0.0131)\end{array}$ & $\begin{array}{c}0.0287 \\
(0.0109)\end{array}$ & $p=.1344$ & 0.5498 & $\begin{array}{l}-0.0002 \\
(0.0061)\end{array}$ & $\begin{array}{l}-0.0088 \\
(0.0083)\end{array}$ & $p=.3511$ & 278489 \\
\hline Natives & $\begin{array}{l}-0.0059 \\
(0.0099)\end{array}$ & $\begin{array}{c}0.0254 \\
(0.0085)\end{array}$ & $p=.0891$ & 0.6451 & $\begin{array}{c}0.0020 \\
(0.0053)\end{array}$ & $\begin{array}{l}-0.0079 \\
(0.0082)\end{array}$ & $p=.5056$ & 510614 \\
\hline Immigrants & $\begin{array}{c}-0.0211 \\
(0.0197)\end{array}$ & $\begin{array}{c}0.0313 \\
(0.0100)\end{array}$ & $p=.6825$ & 0.5997 & $\begin{array}{l}-0.0148 \\
(0.0102)\end{array}$ & $\begin{array}{l}-0.0231 \\
(0.0132)\end{array}$ & $p=.0811$ & 33628 \\
\hline
\end{tabular}

Reform variables are coded 1 for liberalizing reforms and -1 for reforms increasing restrictions or protections.

Controls include female-youth interactions, country-specific youth effects, and year dummies. Observations are weighted using ECHP sampling weights adjusted so that each country receives the same weight. Standard errors are clustered at the country level. 
Table 5: Individual Fixed Effects Results for the Impact of Less Restrictive Protection on the Incidence of Temporary Employment, Wage and Salary Workers

\section{Effects of Reforms: Country Trends Excluded}

\section{Effects of Reforms: Country Trends Included}

\begin{tabular}{|c|c|c|c|c|c|c|c|c|}
\hline Sample & $\begin{array}{l}\text { Temporary } \\
\text { Employment }\end{array}$ & $\begin{array}{l}\text { Permanent } \\
\text { Employment }\end{array}$ & $\begin{array}{l}\text { Test: } \\
b_{\text {perm }}+b_{\text {temp }}=0\end{array}$ & $\begin{array}{l}\text { Mean of } \\
\text { Dependent } \\
\text { Variable }\end{array}$ & $\begin{array}{l}\text { Temporary } \\
\text { Employment }\end{array}$ & $\begin{array}{l}\text { Permanent } \\
\text { Employment }\end{array}$ & $\begin{array}{l}\text { Test: } \\
b_{\text {perm }}+b_{\text {temp }}=0\end{array}$ & Sample Size \\
\hline All & $\begin{array}{c}0.0219 \\
(0.0113)\end{array}$ & $\begin{array}{l}-0.0315 \\
(0.0099)\end{array}$ & $p=.3114$ & 0.1090 & $\begin{array}{c}0.0055 \\
(0.0022)\end{array}$ & $\begin{array}{l}-0.0006 \\
(0.0027)\end{array}$ & $p=.0637$ & 249431 \\
\hline Youth & $\begin{array}{c}0.0343 \\
(0.0214)\end{array}$ & $\begin{array}{l}-0.0710 \\
(0.0471)\end{array}$ & $p=.5342$ & 0.2922 & $\begin{array}{c}0.0095 \\
(0.0172)\end{array}$ & $\begin{array}{l}-0.0264 \\
(0.0229)\end{array}$ & $p=.4334$ & 29570 \\
\hline Adults & $\begin{array}{c}0.0198 \\
(0.0107)\end{array}$ & $\begin{array}{l}-0.0302 \\
(0.0086)\end{array}$ & $p=.2068$ & 0.0861 & $\begin{array}{c}0.0030 \\
(0.0024)\end{array}$ & $\begin{array}{l}-0.0002 \\
(0.0020)\end{array}$ & $p=.2012$ & 219861 \\
\hline Men & $\begin{array}{c}0.0211 \\
(0.0083)\end{array}$ & $\begin{array}{l}-0.0285 \\
(0.0073)\end{array}$ & $p=.3520$ & 0.0973 & $\begin{array}{c}0.0060 \\
(0.0035)\end{array}$ & $\begin{array}{l}-0.0049 \\
(0.0056)\end{array}$ & $p=.8282$ & 142019 \\
\hline Women & $\begin{array}{c}0.0252 \\
(0.0176)\end{array}$ & $\begin{array}{l}-0.0385 \\
(0.0161)\end{array}$ & $p=.3317$ & 0.1241 & $\begin{array}{c}0.0053 \\
(0.0043)\end{array}$ & $\begin{array}{c}0.0034 \\
(0.0026)\end{array}$ & $p=.0167$ & 107412 \\
\hline Natives & $\begin{array}{c}0.0217 \\
(0.0114)\end{array}$ & $\begin{array}{l}-0.0315 \\
(0.0094)\end{array}$ & $p=.3049$ & 0.1082 & $\begin{array}{c}0.0056 \\
(0.0019)\end{array}$ & $\begin{array}{l}-0.0006 \\
(0.0031)\end{array}$ & $p=.0907$ & 234627 \\
\hline Immigrants & $\begin{array}{c}0.0141 \\
(0.0187)\end{array}$ & $\begin{array}{l}-0.0493 \\
(0.0407)\end{array}$ & $p=.3393$ & 0.1314 & $\begin{array}{l}-0.0118 \\
(0.0190)\end{array}$ & $\begin{array}{l}-0.0249 \\
(0.0412)\end{array}$ & $p=.4894$ & 14804 \\
\hline Low Education & $\begin{array}{c}0.0217 \\
(0.0178)\end{array}$ & $\begin{array}{l}-0.0389 \\
(0.0170)\end{array}$ & $p=.2644$ & 0.1191 & $\begin{array}{l}-0.0035 \\
(0.0053)\end{array}$ & $\begin{array}{c}0.0012 \\
(0.0091)\end{array}$ & $p=.8310$ & 82214 \\
\hline $\begin{array}{l}\text { Middle or High } \\
\text { Education }\end{array}$ & $\begin{array}{c}0.0208 \\
(0.0069)\end{array}$ & $\begin{array}{l}-0.0284 \\
(0.0073)\end{array}$ & $p=.2708$ & 0.1033 & $\begin{array}{c}0.0096 \\
(0.0039)\end{array}$ & $\begin{array}{l}-0.0035 \\
(0.0033)\end{array}$ & $p=.3231$ & 167217 \\
\hline
\end{tabular}

Reform variables are coded 1 for liberalizing reforms and -1 for reforms increasing restrictions or protections. Controls include female-youth and female-education interactions, country-specific youth and education effects, and year dummies. Observations are weighted using ECHP sampling weights adjusted so that each country receives the same total weight. Standard errors are clustered at the country level. 
Table 6: Individual Fixed Effects Results for the Impact of Less Restrictive Protection on the Incidence of Employment, by Country (country trends included)

\section{Effects of Reforms}

\begin{tabular}{|c|c|c|c|}
\hline Country & Temporary Employment & Permanent Employment & Sample Size \\
\hline Belgium & $\begin{array}{l}-0.0038 \\
(0.0046)\end{array}$ & & 30883 \\
\hline Finland & & $\begin{array}{l}-0.0166 \\
(0.0052)\end{array}$ & 37173 \\
\hline France & & $\begin{array}{l}-0.0297 \\
(0.0038)\end{array}$ & 66899 \\
\hline Germany & $\begin{array}{c}0.0040 \\
(0.0035)\end{array}$ & & 70424 \\
\hline Italy & $\begin{array}{l}-0.0139 \\
(0.0027)\end{array}$ & & 93865 \\
\hline Netherlands & $\begin{array}{l}-0.0025 \\
(0.0041)\end{array}$ & & 53147 \\
\hline Portugal & $\begin{array}{l}-0.0038 \\
(0.0036)\end{array}$ & & 62901 \\
\hline Spain & $\begin{array}{l}-0.0219 \\
(0.0042)\end{array}$ & $\begin{array}{l}-0.0088 \\
(0.0039)\end{array}$ & 78620 \\
\hline UK & & $\begin{array}{c}0.0105 \\
(0.0039)\end{array}$ & 50330 \\
\hline
\end{tabular}

Reform variables are coded 1 for liberalizing reforms and -1 for reforms increasing restrictions or protections.

Controls include youth, a female-youth interaction, and a trend, with

a separate regression for each country. ECHP sampling weights are used. 
Table 7: Individual Fixed Effects Results for the Impact of Less Restrictive Protection on the Incidence of Temporary Employment, Wage and Salary Workers, by Country (country trends included)

Effects of Reforms

\begin{tabular}{|c|c|c|c|}
\hline Country & Temporary Employment & Permanent Employment & Sample Size \\
\hline Belgium & $\begin{array}{c}0.0197 \\
(0.0053)\end{array}$ & & 14994 \\
\hline Finland & & $\begin{array}{l}-0.0100 \\
(0.0050)\end{array}$ & 18829 \\
\hline France & & $\begin{array}{c}0.0135 \\
(0.0031)\end{array}$ & 33218 \\
\hline Germany & $\begin{array}{c}0.0125 \\
(0.0032)\end{array}$ & & 37477 \\
\hline Italy & $\begin{array}{c}0.0244 \\
(0.0033)\end{array}$ & & 32818 \\
\hline Netherlands & $\begin{array}{l}-0.0031 \\
(0.0030)\end{array}$ & & 27869 \\
\hline Portugal & $\begin{array}{c}0.0088 \\
(0.0045)\end{array}$ & & 26300 \\
\hline Spain & $\begin{array}{c}0.0084 \\
(0.0065)\end{array}$ & $\begin{array}{c}0.0169 \\
(0.0064)\end{array}$ & 28663 \\
\hline UK & & $\begin{array}{c}0.0036 \\
(0.0031)\end{array}$ & 29263 \\
\hline
\end{tabular}

Reform variables are coded 1 for liberalizing reforms and -1 for reforms increasing restrictions or protections.

Controls include female, youth, education, female-youth, female-education interactions, and a trend, with a separate regression for each country. ECHP sampling weights are used. 
Table 8: Effect of Liberalizing Reforms on Year-to-Year Transitions from Permanent Jobs (individual fixed effects models)

Effects of Reforms on Transitions from Permanent Jobs to:

\begin{tabular}{|c|c|c|c|c|c|c|c|}
\hline \multirow[b]{2}{*}{ Sample } & \multicolumn{2}{|c|}{ Nonemployment } & \multicolumn{2}{|c|}{ Temporary Jobs } & \multicolumn{2}{|c|}{ Permanent Jobs } & \multirow[b]{2}{*}{$\begin{array}{c}\text { Sample } \\
\text { Size }\end{array}$} \\
\hline & $\begin{array}{l}\text { Temporary } \\
\text { Employment } \\
\text { Reforms }\end{array}$ & $\begin{array}{l}\text { Permanent } \\
\text { Employment } \\
\text { Reforms }\end{array}$ & $\begin{array}{l}\text { Temporary } \\
\text { Employment } \\
\text { Reforms }\end{array}$ & $\begin{array}{c}\text { Permanent } \\
\text { Employment } \\
\text { Reforms }\end{array}$ & $\begin{array}{l}\text { Temporary } \\
\text { Employment } \\
\text { Reforms }\end{array}$ & $\begin{array}{l}\text { Permanent } \\
\text { Employment } \\
\text { Reforms }\end{array}$ & \\
\hline Belgium & $\begin{array}{c}0.0196 \\
(0.0046)\end{array}$ & & $\begin{array}{c}0.0020 \\
(0.0037)\end{array}$ & & $\begin{array}{l}-0.0216 \\
(0.0059)\end{array}$ & & 10805 \\
\hline Finland & & $\begin{array}{l}-0.0227 \\
(0.0047)\end{array}$ & & $\begin{array}{l}-0.0064 \\
(0.0029)\end{array}$ & & $\begin{array}{c}0.0291 \\
(0.0055)\end{array}$ & 12127 \\
\hline France & & $\begin{array}{c}0.0276 \\
(0.0040)\end{array}$ & & $\begin{array}{l}-0.0025 \\
(0.0017)\end{array}$ & & $\begin{array}{l}-0.0251 \\
(0.0043)\end{array}$ & 23987 \\
\hline Italy & $\begin{array}{c}0.0306 \\
(0.0034)\end{array}$ & & $\begin{array}{c}0.0223 \\
(0.0025)\end{array}$ & & $\begin{array}{l}-0.0530 \\
(0.0042)\end{array}$ & & 23795 \\
\hline Netherlands & $\begin{array}{l}-0.0070 \\
(0.0037)\end{array}$ & & $\begin{array}{c}0.0015 \\
(0.0018)\end{array}$ & & $\begin{array}{c}0.0055 \\
(0.0041)\end{array}$ & & 20454 \\
\hline Spain & $\begin{array}{c}0.0109 \\
(0.0047)\end{array}$ & $\begin{array}{c}0.0172 \\
(0.0047)\end{array}$ & $\begin{array}{l}-0.0089 \\
(0.0042)\end{array}$ & $\begin{array}{c}0.0078 \\
(0.0042)\end{array}$ & $\begin{array}{l}-0.0020 \\
(0.0062)\end{array}$ & $\begin{array}{l}-0.0251 \\
(0.0062)\end{array}$ & 14835 \\
\hline UK & & $\begin{array}{c}0.0112 \\
(0.0041)\end{array}$ & & $\begin{array}{l}-0.0005 \\
(0.0025)\end{array}$ & & $\begin{array}{l}-0.0107 \\
(0.0047)\end{array}$ & 22140 \\
\hline
\end{tabular}

Models are estimated in differences from person-specific means.

Reform variables are coded 1 for liberalizing reforms and -1 for reforms increasing restrictions or protections.

Controls include youth, a female-youth interactions, and a trend, with a separate regression for each country.

ECHP sampling weights are

used. 
Table 9: Effect of Liberalizing Reforms on Year-to-Year Transitions from Nonemployment (individual fixed effects models)

Effects of Reforms on Transitions from Nonemployment to:

\begin{tabular}{|c|c|c|c|c|c|c|c|}
\hline \multirow[b]{2}{*}{ Sample } & \multicolumn{2}{|c|}{ Nonemployment } & \multicolumn{2}{|c|}{ Temporary Jobs } & \multicolumn{2}{|c|}{ Permanent Jobs } & \multirow[b]{2}{*}{$\begin{array}{c}\text { Sample } \\
\text { Size }\end{array}$} \\
\hline & $\begin{array}{l}\text { Temporary } \\
\text { Employment } \\
\text { Reforms }\end{array}$ & $\begin{array}{l}\text { Permanent } \\
\text { Employment } \\
\text { Reforms }\end{array}$ & $\begin{array}{l}\text { Temporary } \\
\text { Employment } \\
\text { Reforms }\end{array}$ & $\begin{array}{c}\text { Permanent } \\
\text { Employment } \\
\text { Reforms }\end{array}$ & $\begin{array}{l}\text { Temporary } \\
\text { Employment } \\
\text { Reforms }\end{array}$ & $\begin{array}{l}\text { Permanent } \\
\text { Employment } \\
\text { Reforms }\end{array}$ & \\
\hline Belgium & $\begin{array}{l}-0.0003 \\
(0.0066)\end{array}$ & & $\begin{array}{l}-0.0025 \\
(0.0045)\end{array}$ & & $\begin{array}{c}0.0028 \\
(0.0053)\end{array}$ & & 7075 \\
\hline Finland & & $\begin{array}{c}0.0892 \\
(0.0114)\end{array}$ & & $\begin{array}{l}-0.0376 \\
(0.0094)\end{array}$ & & $\begin{array}{l}-0.0516 \\
(0.0073)\end{array}$ & 8331 \\
\hline France & & $\begin{array}{c}0.0416 \\
(0.0059)\end{array}$ & & $\begin{array}{l}-0.0165 \\
(0.0044)\end{array}$ & & $\begin{array}{l}-0.0252 \\
(0.0043)\end{array}$ & 16674 \\
\hline Italy & $\begin{array}{l}-0.0090 \\
(0.0032)\end{array}$ & & $\begin{array}{c}0.0087 \\
(0.0021)\end{array}$ & & $\begin{array}{c}0.0003 \\
(0.0026)\end{array}$ & & 32943 \\
\hline Netherlands & $\begin{array}{c}0.0129 \\
(0.0077)\end{array}$ & & $\begin{array}{c}0.0099 \\
(0.0041)\end{array}$ & & $\begin{array}{l}-0.0229 \\
(0.0067)\end{array}$ & & 10333 \\
\hline Spain & $\begin{array}{c}-0.0238 \\
(0.0051)\end{array}$ & $\begin{array}{l}-0.0086 \\
(0.0046)\end{array}$ & $\begin{array}{c}0.0314 \\
(0.0046)\end{array}$ & $\begin{array}{c}0.0067 \\
(0.0042)\end{array}$ & $\begin{array}{l}-0.0076 \\
(0.0027)\end{array}$ & $\begin{array}{c}0.0019 \\
(0.0024)\end{array}$ & 29164 \\
\hline UK & & $\begin{array}{l}-0.0389 \\
(0.0084)\end{array}$ & & $\begin{array}{c}0.0012 \\
(0.0043)\end{array}$ & & $\begin{array}{c}0.0376 \\
(0.0074)\end{array}$ & 9262 \\
\hline
\end{tabular}

Models are estimated in differences from person-specific means.

Reform variables are coded 1 for liberalizing reforms and -1 for reforms increasing restrictions or protections.

Controls include youth, a female-youth interactions, and a trend, with a separate regression for each country.

ECHP sampling weights are

used. 
Table 10: Effect of Liberalizing Reforms on Year-to-Year Transitions from Temporary Jobs (individual fixed effects models)

Effects of Reforms on Transitions from Temporary Jobs to:

\begin{tabular}{|c|c|c|c|c|c|c|c|}
\hline \multirow[b]{2}{*}{ Sample } & \multicolumn{2}{|c|}{ Nonemployment } & \multicolumn{2}{|c|}{ Temporary Jobs } & \multicolumn{2}{|c|}{ Permanent Jobs } & \multirow[b]{2}{*}{$\begin{array}{c}\text { Sample } \\
\text { Size }\end{array}$} \\
\hline & $\begin{array}{l}\text { Temporary } \\
\text { Employment } \\
\text { Reforms }\end{array}$ & $\begin{array}{l}\text { Permanent } \\
\text { Employment } \\
\text { Reforms }\end{array}$ & $\begin{array}{l}\text { Temporary } \\
\text { Employment } \\
\text { Reforms }\end{array}$ & $\begin{array}{l}\text { Permanent } \\
\text { Employment } \\
\text { Reforms }\end{array}$ & $\begin{array}{l}\text { Temporary } \\
\text { Employment } \\
\text { Reforms }\end{array}$ & $\begin{array}{l}\text { Permanent } \\
\text { Employment } \\
\text { Reforms }\end{array}$ & \\
\hline Belgium & $\begin{array}{c}0.0208 \\
(0.0215)\end{array}$ & & $\begin{array}{l}-0.0894 \\
(0.0461)\end{array}$ & & $\begin{array}{c}0.0685 \\
(0.0434)\end{array}$ & & 979 \\
\hline Finland & & $\begin{array}{c}0.0406 \\
(0.0233)\end{array}$ & & $\begin{array}{l}-0.0165 \\
(0.0320)\end{array}$ & & $\begin{array}{l}-0.0242 \\
(0.0259)\end{array}$ & 1903 \\
\hline France & & $\begin{array}{l}-0.0713 \\
(0.0237)\end{array}$ & & $\begin{array}{c}0.0678 \\
(0.0283)\end{array}$ & & $\begin{array}{c}0.0035 \\
(0.0195)\end{array}$ & 2479 \\
\hline Italy & $\begin{array}{c}0.2199 \\
(0.0252)\end{array}$ & & $\begin{array}{l}-0.2856 \\
(0.0345)\end{array}$ & & $\begin{array}{c}0.0657 \\
(0.0285)\end{array}$ & & 2029 \\
\hline Netherlands & $\begin{array}{c}0.0921 \\
(0.0386)\end{array}$ & & $\begin{array}{c}0.1393 \\
(0.0565)\end{array}$ & & $\begin{array}{l}-0.2313 \\
(0.0500)\end{array}$ & & 691 \\
\hline Spain & $\begin{array}{l}-0.0543 \\
(0.0138)\end{array}$ & $\begin{array}{c}0.0755 \\
(0.0132)\end{array}$ & $\begin{array}{c}0.0761 \\
(0.0202)\end{array}$ & $\begin{array}{l}-0.1604 \\
(0.0193)\end{array}$ & $\begin{array}{l}-0.0218 \\
(0.0167)\end{array}$ & $\begin{array}{c}0.0850 \\
(0.0159)\end{array}$ & 6842 \\
\hline UK & & $\begin{array}{c}0.0473 \\
(0.0318)\end{array}$ & & $\begin{array}{l}-0.1966 \\
(0.0562)\end{array}$ & & $\begin{array}{c}0.1493 \\
(0.0515)\end{array}$ & 941 \\
\hline
\end{tabular}

Models are estimated in differences from person-specific means.

Reform variables are coded 1 for liberalizing reforms and -1 for reforms increasing restrictions or protections.

Controls include youth, a female-youth interactions, and a trend, with a separate regression for each country.

ECHP sampling weights are

used. 
Table A1: Incidence of Temporary Employment Among Employees, by Gender, ECHP and OECD

ECHP

OECD

\begin{tabular}{lcccccc} 
Country & Men & N & Women & N & Men & Women \\
\hline Belgium & 0.065 & 8210 & 0.116 & 6784 & 0.121 & 0.066 \\
Finland & 0.109 & 9312 & 0.161 & 9517 & 0.209 & 0.145 \\
France & 0.089 & 18040 & 0.100 & 15178 & 0.157 & 0.143 \\
Germany & 0.068 & 21456 & 0.087 & 16021 & 0.131 & 0.125 \\
Italy & 0.068 & 19927 & 0.084 & 12891 & 0.122 & 0.088 \\
Netherlands & 0.028 & 16592 & 0.055 & 11277 & 0.172 & 0.115 \\
Portugal & 0.100 & 14995 & 0.141 & 11305 & 0.227 & 0.186 \\
Spain & 0.307 & 18657 & 0.325 & 10006 & 0.346 & 0.306 \\
UK & 0.041 & 14830 & 0.048 & 14433 & 0.077 & 0.059 \\
\hline
\end{tabular}

Note: OECD figures are taken from OECD (2002, p. 138) and refer to the year 2000. 